\title{
PENGARUH PENGGUNAAN TEKNOLOGI INFORMASI, KETERLIBATAN PEMAKAI DAN DUKUNGAN MANAJEMEN PUNCAK TERHADAP KINERJA SISTEM INFORMASI AKUNTANSI (STUDI KASUS PADA CV JAYA MOTOR)
}

\author{
Rachma Sukmawati ${ }^{1}$ Dennyca Hendriyanto Nugroho ${ }^{2}$ \\ Program Studi Akuntansi, Fakultas Ekonomi dan Bisnis Universitas Muria Kudus \\ IRachma.Sukmawati@gmail.com \\ 2dennyca.hendriyantonugroho@umk.ac.id
}

\begin{abstract}
ABSTRAK
Penelitian ini bertujuan untuk memperoleh bukti mengenai pengaruh penggunaan teknologi informasi, keterlibatan pemakai, program pelatihan dan pendidikan pemakai, formalisasi pengembangan sistem, dan dukungan manajemen puncak terhadap kinerja sistem informasi akuntansi. Populasi dalam penelitian ini adalah karyawan tetap yang berjumlah 136 orang. Teknik pengumpulan sampel yang digunakan adalah purposive sampling sebanyak 58 orang. Metode pengumpulan data yaitu dengan menggunakan kuesioner yang dibagikan kepada responden. Teknik analisis data menggunakan analisis regresi linear berganda dengan bantuan program SPSS 23.0. Hasil penelitian menunjukkan bahwa (1) penggunaan teknologi informasi berpengaruh positif dan signifikan terhadap kinerja sistem informasi akuntansi, (2) keterlibatan pemakai tidak berpengaruh terhadap kinerja sistem informasi akuntansi, (3) dukungan manajemen puncak berpengaruh positif dan signifikan terhadap kinerja sistem informasi akuntansi.
\end{abstract}

Kata kunci: Penggunaan Teknologi Informasi, Keterlibatan Pemakai, Dukungan Manajemen Puncak Dan Kinerja Sistem Informasi Akuntansi.

\begin{abstract}
This study was aimed at finding evidence for the effect of the use of information technology, user's involvement, user's training and education program, formalization of system development and the support of top management on the performance of accounting information system. The population in this study was 136 of permanent employees. The study used purposive sampling technique and a total of 58 employees. The study used questionnaires which were distributed to the respondents for collecting data. The data were analyzed by multiple linear regression analysis aided by SPSS 23.0 program. The results showed that (1) the use of information technology has a positive and significant effect on the performance of accounting information system, (2) user's involvement has no effect on the performance of accounting information system, (3) the support of top management has a positive and significant effect on the performance of accounting information system.
\end{abstract}




\section{P ISSN}

Keyword: The Use Of Information Technology, User's Involvement, The Support Of Top Management And The Performance Of Accounting Information System.

\section{PENDAHULUAN}

Pesatnya perkembangan dan kemajuan industri dalam dunia usaha saat ini, menyebabkan persaingan yang ketat di berbagai bidang usaha. Salah satunya adalah bidang perdagangan produk sepeda motor. Persaingan antar perusahaan mengharuskan perusahaan memperbaiki dan meningkatkan kinerjanya, terutama pada kinerja sistem informasi akuntansi. Dengan kinerja sistem informasi akuntansi yang baik, maka informasi yang dihasilkan akan akurat dan relevan, sehingga tujuan perusahaan akan tercapai. Baik buruknya suatu kinerja sistem informasi akuntansi dapat dilihat dari faktor-faktor yang dapat mempengaruhi kinerja itu sendiri.

Menurut Arini, dkk (2017) suatu sistem informasi akan sukses apabila didukung oleh beberapa faktor pendukungnya. Faktor yang pertama adalah penggunaan teknologi informasi, hasil penelitian yang dilakukan oleh Arini, dkk (2017) menunjukan bahwa, semakin tinggi penggunaan teknologi informasi maka kinerja sistem informasi akuntansi akan meningkat. Faktor yang kedua adalah keterlibatan pemakai, Jen (2002) dan Komara (2005) dalam Abhimantara dan Suryanawa (2016) berpendapat bahwa keterlibatan pemakai yang semakin sering akan meningkatkan kinerja sistem informasi akuntansi dikarenakan adanya hubungan yang positif antara keterlibatan pemakai dalam proses pengembangan sistem informasi dalam kinerja sistem informasi akuntansi. Faktor yang ketiga dukungan manajemen puncak. Menurut Fani, dkk (2015) bila manajemen puncak memberikan dukungan penuh dalam pengembangan sistem informasi dan dukungan tersebut dapat diterima oleh pengguna informasi, maka akan memberikan kepuasan terhadap informasi tersebut.

Di Indonesia telah banyak perusahaan yang memakai sistem informasi dalam kegiatan operasi perusahaannya, dan tidak sedikit pula yang mengalami kegagalan dalam pengembangan sistem yang berdampak terhadap kinerja sistem informasi. Fenomena yang sering terjadi adalah banyaknya pengguna sistem informasi baik internal maupun eksternal yang tidak puas terhadap kinerja sistem informasi yang telah dikembangkan dan diterapkan pada perusahaan tersebut, salah satunya adalah perusahaan dagang CV Jaya Motor. Dalam 
pengembangan dan penerapan sistem informasi akuntansi oleh CV Jaya Motor selama ini, tentunya tidak terlepas dari berbagai macam kendala. Setelah peneliti mengadakan observasi melalui wawancara secara langsung terhadap beberapa pengguna sistem informasi akuntasi yang bekerja pada CV Jaya Motor, ternyata ditemukan berbagai macam kendala antara lain adalah kurang maksimalnya kinerja sistem yang digunakan seperti lambatnya sistem pada saat proses dan pengolahan data transaksi bahkan terkadang sistem mengalami error serta tidak adanya buku panduan khusus dalam mengoperasikan sistem.

Berdasarkan uraian diatas telah menyebutkan fenomena dan penelitian terdahulu yang berkenaan dengan penggunaan teknologi informasi, keterlibatan pemakai dan dukungan manajemen puncak terhadap kinerja sistem informasi akuntansi. Oleh sebab itu, perlu diadakan penelitian kembali dengan judul penelitian "Pengaruh Penggunaan Teknologi Informasi, Keterlibatan Pemakai dan Dukungan Manajemen Puncak Terhadap Kinerja Sistem Informasi Akuntansi (Studi Kasus Pada CV Jaya Motor )”.

\section{Rumusan Masalah}

1. Apakah penggunaan teknologi informasi berpengaruh terhadap kinerja sistem informasi akuntansi?

2. Apakah keterlibatan pemakai berpengaruh terhadap kinerja sistem informasi akuntansi?

3. Apakah dukungan manajemen puncak berpengaruh terhadap kinerja sistem informasi akuntansi?

\section{Tujuan Penelitian}

Berdasarkan latar belakang dan perumusan masalah yang telah diuraikan, tujuan yang ingin dicapai dalam penelitian ini adalah untuk menguji pengaruh penggunaan teknologi informasi, keterlibatan pemakai dan dukungan manajemen puncak terhadap kinerja sistem informasi akuntansi.

\section{TINJAUAN PUSTAKA}

\section{Human Organization Technology (HOT)}

Menurut Yusof et al (2006) dalam Arini, dkk (2017) Human Organization Technology (HOT) merupakan suatu kerangkan baru yang dapat digunakan untuk melakukan evaluasi 
sistem informasi. Teori ini menempatkan komponen penting dalam sistem informasi akuntansi yakni manusia (human), organisasi (organization), dan teknologi (technology) serta kesesuaian hubungan satu sama lainnya. Komponen manusia (human) menilai sistem informasi dari sisi penggunaan sistem (system use) pada frekuensi dan luasnya fungsi dan penyelidikan sistem informasi. System use juga berhubungan dengan siapa yang menggunakan (who use it), tingkat penggunanya (level of user), pelatihan,

\section{Task Technology Fit (TIF)}

TIF dikembangkan oleh Goodhue dan Thompson (1995). TIF adalah tingkat dimana teknologi membantu individu dalam pelaksanaan tugas-tugasnya atau tugas jabatan. Secara lebih spesifik, TIF merupakan penyesuaian antara kebutuhan akan tugas-tugas, kemampuan individu dan fungsi teknologi. Prioritas TIF adalah interaksi anatara tugas, teknologi, dan individu (Goodhue dan Thompson (1995) dalam Chalik, 2017).

\section{Kinerja Sistem Informasi Akuntansi}

Menurut Kasmir (2016:182) kinerja adalah hasil kerja dan perilaku kerja yang telah dicapai dalam menyelesaikan tugas-tugas dan tanggung jawab yang diberikan dalam suatu periode tertentu. Berdasarkan uraian diatas, dapat disimpulkan bahwa kinerja sistem informasi akuntansi adalah penilaian terhadap hasil kerja dan perilaku kerja para pemakai sistem dalam menyelesaikan tugasnya sesuai dengan waktu yang telah ditentukan, untuk menghasilkan informasi akuntansi maupun keuangan yang berguna dalam pengambilan keputusan untuk mencapai tujuan perusahaan.

\section{Penggunaan Teknologi Informasi}

Menurut Jogiyanto (2009:7) teknologi yang digunakan di sistem teknologi informasi adalah teknologi komputer, teknologi telekomunikasi dan teknologi apapun yang dapat memberikan nilai tambah untuk organisasi.

\section{Keterlibatan Pemakai}

Menurut Arini, dkk (2017) keterlibatan pemakai adalah perilaku, pernyataan, dan aktivitas yang dilakukan pemakai dalam proses pengembangan sistem informasi.

\section{Dukungan Manajemen Puncak}

Menurut Griffin dalam Lubis (2010:47) menyatakan bahwa menajemen sebagai sebuah proses perencanaan, pengorganisasian, pengoordinasian, dapengendalian sumber daya untuk mencapai sasaran (goals) secara efektif dan efisien. 


\section{P ISSN \\ [ACCOUNTING GLOBAL JOURNAL] E ISSN}

\section{Kerangka Pemikiran Teoritis}

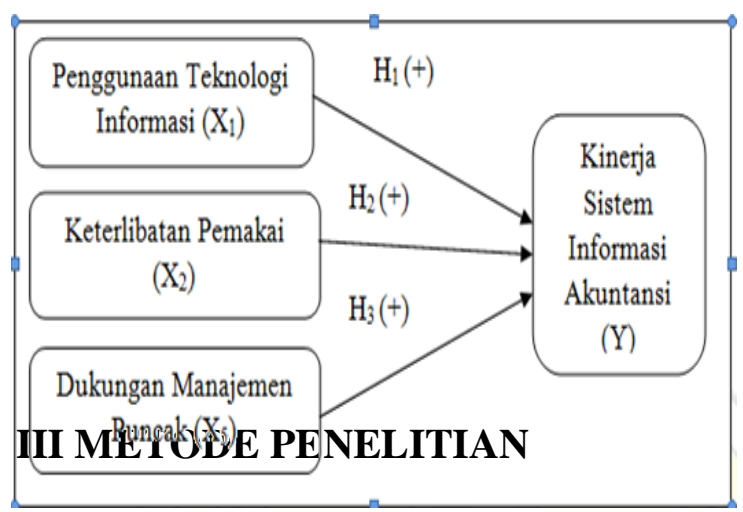

\section{Pengumpulan Data dan Pengukuran Variabel}

Dalam penelitian ini teknik pengumpulan data yang digunakan adalah metode angket yang sering disebut juga metode kuesioner dengan menggunakan skala likert sebagai pengukuran variabel

\section{Kinerja Sistem Informasi Akuntansi}

Menurut Almilia dan Briliantien (2007) dalam Abhimantra dan Suryanawa (2016) indikator pengukuran untuk kinerja sistem informasi akuntansi (Y) adalah sebagai berikut:

1. Sistem informasi akuntansi penting dalam kesuksesan kinerja di departemen.

2. Sistem informasi akuntansi mampu meningkatkan kepuasan bekerja.

3. Pengguna senang menggunakan sistem yang ada.

4. Dengan menggunakan sistem yang ada, Pengguna mampu mengerjakan tugas lebih mudah dan lebih efisien.

5. Karyawan tertarik untuk menggunakan sistem yang ada.

6. Sistem mampu menghasilkan informasi yang tepat pada waktunya.

7. Sistem selalu memberikan informasi yang dibutuhkan di bagian anda.

8. Frekuensi penggunaan sistem informasi akuntansi.

9. Kesediaan menggunakan sistem informasi.

10. Pemahaman terhadap sistem informasi. 


\section{P ISSN}

\section{Penggunaan Teknologi Informasi}

Menurut Compeau (1999) dalam Fuad Mas'ud (2004:535-536) indikator pengukuran untuk penggunaan teknologi informasi $\left(\mathrm{X}_{1}\right)$ adalah sebagai berikut:

1. Penggunaan teknologi informasi dapat meningkatkan keefektifan kerja.

2. Penggunaan teknologi informasi dapat mengurangi waktu dalam pekerjaan-pekerjaan rutin.

3. Penggunaan teknologi informasi dapat meningkatkan kuantitas hasil pekerjaan dengan tingkat usaha yang sama.

4. Penggunaan teknologi informasi dapat menjadikan karyawan sebagai orang yang kompeten.

\section{Keterlibatan Pemakai}

Menurut Almilia dan Briliantien (2007) dalam Abhimantra dan Suryanawa (2016) indikator pengukur untuk keterlibatan pemakai $\left(\mathrm{X}_{2}\right)$ adalah sebagai berikut:

1. Tingkat partisipasi dalam pengembangan sistem informasi.

2. Tingkat pengaruh dalam pengembangan sistem informasi.

3. Tingkat kesediaan dalam memberikan informasi mengenai keunggulan dan kelemahan dari sistem informasi yang dioperasikan ditempat bekerja.

\section{Dukungan Manajemen Puncak}

Menurut Almilia dan Briliantien (2007) dalam Abhimantra dan Suryanawa (2016) indikator pengukuran untuk dukungan manajemen puncak $\left(\mathrm{X}_{3}\right)$ adalah sebagai berikut:

1. Manajemen puncak mahir dalam menggunakan komputer.

2. Manajemen puncak memiliki harapan yang tinggi terhadap penggunaan sistem.

3. Manajemen puncak secara aktif terlibat dalam perencanaan operasi sistem informasi.

4. Manajemen puncak memberikan perhatian tinggi terhadap evaluasi kinerja dari sistem informasi.

5. Manajemen puncak mendukung proses pengembangan sistem informasi akuntansi yang dioperasikan ditempat bekerja agar dapat meningkatkan kepuasan pemakai sistem informasi.

\subsection{Jenis Dan Sumber Data}




\section{P ISSN}

Sumber data primer dalam penelitian ini adalah jawaban responden dari kuesioner yang disebar pada Head Office dan sepuluh cabang perusahaan CV Jaya Motor. Sedangkan data sekunder dalam penelitian ini adalah penjelasan atau gambaran umum perusahaan.

\subsection{Populasi Dan Sampel}

Populasi dalam penelitian ini adalah karyawan tetap CV Jaya Motor yang berjumlah 136 orang dan bertugas di Head Office dan sepuluh cabang yaitu Kudus, Jekulo, Mulyoharjo, Welahan, Pecangaan, Demak, Mranggen, Semarang, Rembang dan Sidoarjo. Penelitian ini menggunakan teknik purposive sampling yaitu mengambil sampel dari populasi berdasarkan kriteria tertentu (Jogiyanto, 2008:76). Kriteria dalam pemilihan sampel adalah sebagai berikut:

1. Pengguna sistem informasi akuntansi.

2. Karyawan tetap yang masa kerjanya minimal 3 tahun.

3. Karyawan yang aktif (tidak cuti/pendidikan).

\section{Metode Analisis Data}

Data yang telah terkumpul akan diolah menggunakan program SPSS (Statistical Package For Social Science) versi 23.0. Dalam penelitian ini menggunakan regresi linear berganda sebagai alat analisis data. Model persamaan regresi yang digunakan dalam penelitian ini adalah sebagai berikut:

Sumber : Basuki dan Prawoto (2016:4)

Keterangan :

Y : :Kinerja sistem informasi akuntansi

$\alpha \quad$ : Koefisien konstanta

$$
\mathrm{Y}=\alpha+\beta_{1} \mathrm{X}_{1}+\beta_{2} \mathrm{X}_{2}+\beta_{3} \mathrm{X}_{3}+\mathrm{e}
$$

$\mathrm{X}_{2} \quad$ : Keterlibatan pemakai

$\mathrm{X}_{3}$ : Dukungan manajemen puncak

e : Error

\section{HASIL DAN PEMBAHASAN}

Uji Instrumen Data 


\section{P ISSN}

\section{Uji Validitas}

Uji validitas terhadap instrumen dilakukan untuk menjamin bahwa instrumen yang digunakan akurat dan dapat dipercaya sebagai alat pengumpulan data. Suatu skala dikatakan mempunyai keahlian atau validitas, bila skala itu mengukur apa yang seharusnya diukur (Nasution, 2001:57). Hasil uji validitas dalam penelitian ini menyatakan masing-masing variabel memiliki nilai $\mathrm{r}$ hitung $>\mathrm{r}$ tabel $(0,2181)$ yang berarti semua item pernyataan dinyatakan valid.

\section{Uji Reliabilitas}

Suatu skala dianggap reliable yaitu dapat dipercaya, apabila secara konsisten memberikan hasil yang sama jika diterapkan pada sampel yang sama pada waktu yang berbeda (Nasution, 2001:56). Hasil uji reliabilitas dalam penelitian ini menunjukkan bahwa masing-masing variabel dalam penelitian ini memiliki nilai Alpha Cronbach lebih dari 0,70. Dengan demikian dapat dinyatakan bahwa semua varibel adalah reliable.

\section{Uji Asumsi Klasik}

\section{Uji Normalitas}

Uji normalitas dilakukan untuk menguji apakah dalam model regresi variabel penganggu atau residual memiliki distribusi normal. Model regresi yang baik adalah yang berdistribusi normal atau mendekati normal. Pengujian ini dilakukan dengan menggunakan uji Kolmogorov Smirnov, yaitu dengan membandingkan asymptotic significance dengan alpha 0,05. (Basuki dan Prawoto, 2016:60). Hasil uji normalitas dalam penelitian ini menunjukkan bahwa nilai Asymp. Sig. (2-tailed) adalah 0.200 dimana nilai ini lebih besar dari 0.05. Hal ini menunjukkan bahwa data berdistribusi secara normal. Dengan demikian uji normalitas terpenuhi.

\section{Uji Multikolinearitas}

Uji multikolinearitas bertujuan untuk menguji apakah model regresi ditemukan adanya kolerasi antar variabel bebas atau independent. Model regresi yang baik adalah regresi yang tidak adanya gejala kolerasi yang kuat diantara variabel bebasnya. (Basuki dan Prawoto, 2016:62). 
Tabel 4.1

\section{Hasil Uji Multikolinearitas}

\begin{tabular}{|c|c|c|c|}
\hline \multirow{2}{*}{\multicolumn{2}{|c|}{ Model }} & \multicolumn{2}{|c|}{$\begin{array}{l}\text { Collineanty } \\
\text { Statistics }\end{array}$} \\
\hline & & Tolerance & VIF \\
\hline 1 & (Constant) & & \\
\hline & PENGGUNAAN_TI & .765 & 1,307 \\
\hline & KETERLIBATAN PEMAKAI & 860 & $1_{i} ; 63$ \\
\hline & DUKUNGAN_MP & 836 & 1,196 \\
\hline
\end{tabular}

Sumber: Data primer yang diolah, 2018.

Hasil uji multikolinearitas dalam penelitian ini menunjukkan bahwa masing-masing variabel memliki nilai Tolerance lebih dari 0,10 dan nilai VIF menunjukkan nilai kurang dari 10. Dengan demikian dapat disimpulkan bahwa tidak terdapat multikolinearitas diantara variabel independen atau variabel bebas dalam penelitian ini.

\section{Uji Heteroskedasitas}

Uji heteroskedasitas adalah untuk melihat apakah terdapat ketidaksamaan varians dari residual satu pengamatan ke pengamatan yang lain. Model regresi residual satu pengamatan ke pengamatan lain tetap atau disebut homoskedasitas. ketentuan apabila memiliki nilai signifikansi lebih besar dari 0,05 maka model regresi dinyatakan tidak mengandung adanya heteroskedasitas. (Imam Ghozali, 2016:134-138). Pungujian heteroskedasitas ini menggunakan metode Uji Glejser.

Tabel. 4.2

Hasil Uji Heteroskedasitas

\begin{tabular}{|c|c|c|}
\hline \multicolumn{2}{|c|}{ Model } & Sig. \\
\hline 1 & (Constant) & 687 \\
\hline & PENGGUNAAN_TI & 116 \\
\hline & KETERLIBATAN PEMAKAI & 624 \\
\hline & DUKUNGAN_MP & 752 \\
\hline
\end{tabular}




\section{P ISSN \\ [ACCOUNTING GLOBAL JOURNAL] E ISSN}

Berdasarkan menunjukkan bahwa keseluruhan variabel memiliki nilai signifikan lebih besar dari 0,05 sehingga data penelitian dapat disimpulkan tidak mengandung heteroskedasitas.

\section{Uji Regresi Linear Berganda}

Uji regresi linear berganda digunakan untuk menguji pengaruh dua atau lebih variabel independen terhadap satu variabel dependen. Berikut disajikan tabel hasil uji regresi linear berganda:

Tabel 4.3

Hasil Uji Linear Berganda

\begin{tabular}{|c|c|c|c|c|c|c|}
\hline \multirow[b]{2}{*}{ Model } & & \multicolumn{2}{|c|}{ Unstandardized Coefficicints } & \multirow{2}{*}{$\begin{array}{c}\text { Standardized } \\
\text { Coefficientis } \\
\text { Befla } \\
\end{array}$} & \multirow[b]{2}{*}{1} & \multirow[b]{2}{*}{ Sig. } \\
\hline & & $B$ & Sitd. Error & & & \\
\hline 1 & (Constant) & 2,987 & 5,470 & & .546 & .587 \\
\hline & PENGGUNAAN II & 1,046 &, 255 & 45 & 4,100 & .000 \\
\hline & KEEERLBATAN PENAKAI & 391 & .222 & 137 & 1,340 &, 186 \\
\hline & DUKUNGAN_MP & 799 & .248 & .335 & 3.229 & .002 \\
\hline
\end{tabular}

Sumber: Data primer yang diolah, 2018

Berdasarkan Tabel 4.3, konstanta dan koefisien regresi yang diperoleh maka persamaan regresi yang dibentuk adalah: $\mathrm{Y}=2,987+1$

\section{Uji Hipotesis}

\section{Uji Koefisien Determinasi $\left(\mathbf{R}^{2}\right)$}

Uji koefisien determinasi digunakan untuk mengukur proposi atau presentase sumbangan variabel independen yang diteliti terhadap variasi naik turunnya variabel dependen.

Tabel 4.4

Hasil Uji $\mathbf{R}^{2}$

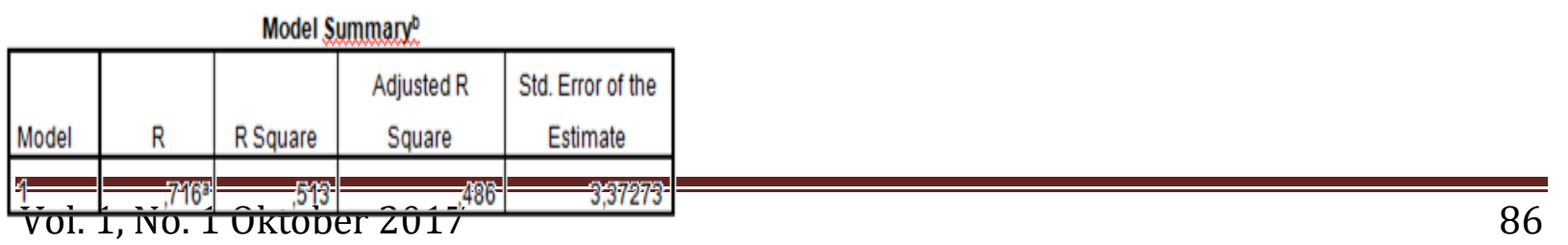




\section{P ISSN \\ [ACCOUNTING GLOBAL JOURNAL] E ISSN}

Sumber: Data primer yang diolah, 2018.

Berdasarkan Tabel 4.4 di atas, nilai Adjusted $\mathrm{R}^{2}$ sebesar 0,486 yang berarti bahwa variabel penggunaan teknlogi informasi, keterlibatan pemakai, dan dukungan manajemen puncak dalam penelitian ini mampu mempengaruhi variabel kinerja sistem informasi akuntansi sebesar $48,6 \%$ dan sisanya $51,4 \%$ dipengaruhi oleh variabel independen lainnya yang tidak diikutsertakan dalam model regresi.

\section{Uji Simultan (Uji F)}

Uji $\mathrm{F}$ dalam regresi berganda bertujuan untuk mengetahui pengaruh variabel independen terhadap variabel dependen secara simultan. (Basuki dan Prawoto, 2016:51-52).

\section{Tabel 4.5}

\section{Hasil Uji F}

\begin{tabular}{|c|c|c|c|c|c|c|}
\hline \multicolumn{7}{|c|}{ ANOVA: } \\
\hline Mode & & Sum of Squares & dit. & Mean Square & $\mathrm{F}$ & Sig. \\
\hline \multirow[t]{3}{*}{1} & Regression & 646,630 & 3 & 215,543 & 18,948 & $000^{\circ}$ \\
\hline & Residual & 614,267 & 54 & 11,375 & & \\
\hline & Total & 1260,897 & 57 & & & \\
\hline
\end{tabular}

Sumber: Data primer yang diolah, 2018.

Berdasarkan Tabel 4.5, menunjukkan bahwa nilai signifikan ini lebih kecil dari dari nilai $\alpha$ $(0,000<0,05)$. Dengan demikian, disimpulkan bahwa variabel penggunaan teknologi informasi, keterlibatan pemakai dan dukungan manajemen puncak secara bersama-sama berpengaruh terhadap variabel kinerja sistem informasi akuntansi.

\section{Uji t (Uji Parsial)}

Uji t adalah pengujian koefisien regresi parsial individual yang digunakan untuk mengetahui apakah variabel independen secara individual mempengaruhi variabel dependen (Antari, 2015).

Tabel 4.6

Hasil Uji t

\begin{tabular}{|c|c|c|c|}
\hline Waxiabel & Sig & Keterangan & \\
\hline $\begin{array}{l}\text { PENGGUNAA } \\
\text { N_TI }\end{array}$ & 0,000 & Bexpengaruh & \\
\hline Vod,PERA & bersed & 17 Tdk & 87 \\
\hline $\begin{array}{l}\text { DUKUNGAN_ } \\
\text { MP }\end{array}$ & 0,002 & Berpengaruh & \\
\hline
\end{tabular}




\section{Pembahasan}

\section{Pengaruh Penggunaan Teknologi Informasi Terhadap Kinerja Sistem Informasi} Akuntansi

Hasil pengujian hipotesis 1 menunjukkan bahwa penggunaan teknologi informasi berpengaruh positif dan signifikan terhadap kinerja sistem informasi akuntansi. Hal ini menunjukkan bahwa untuk meningkatkan kinerja sistem informasi akuntansi dalam perusahaan CV Jaya Motor, perusahaan mengharuskan karyawan menguasai penggunaan teknologi informasi dengan memanfaatkan aplikasi sistem khusus yang ada pada perusahaan yaitu Dealer Management System. Aplikasi sistem ini membantu karyawan dalam mengolah data transaksi dengan lebih efektif dan efisien untuk menghasilkan laporan keuangan sebagai pengambilan keputusan perusahaan. Dengan penggunaan teknologi informasi yang secara tepat dan dimanfaatkan dengan maksimal menjadikan kinerja sistem informasi akuntansi pada perusahaan meningkat.

Dalam teori TIF dan HOT menjelaskan bahwa penggunaan teknologi informasi yang secara tepat dan dimanfaatkan dengan maksimal dalam mengumpulkan dan memproses data serta evaluasi terhadap kecocokan tugas dengan teknologi maka kinerja sistem informasi akuntansi akan meningkat dan optimal. Kesesuaian hubungan antara manusia, organsasi dan teknologi dapat membantu individu atau karyawan dalam melaksanakan tugasnya dengan efektif dan efisien, sehingga kinerja sistem informasi akuntansi menjadi optimal

Hasil penelitian ini sejalan dan mendukung penelitian yang dilakukan oleh Arini, dkk (2017) yang menunjukkan bahwa penggunaan teknologi informasi berpengaruh positif dan signifikan terhadap kinerja sistem informasi akuntansi.

\section{Pengaruh Keterlibatan Pemakai Terhadap Kinerja Sistem Informasi Akuntansi}

Hasil pengujian hipotesis 2 pada perusahaan CV Jaya Motor menunjukkan bahwa keterlibatan pemakai tidak berpengaruh terhadap kinerja sistem informasi akuntansi, hal ini 
dikarenakan perusahaan tidak setiap tahun mengadakan pengembangan sistem dan tidak semua karyawan dilibatkan dalam pengembangan sistem. Pengembangan sistem pada perusahaan CV Jaya Motor hanya dilakukan pada bagian yang mengakses dan membutuhkan informasi laporan keuangan sebagai pengambilan keputusan seperti pada bagian manajer, finance dan audit, bukan pada karyawan yang berhubungan dengan pengolahan data transaksi seperti pada bagian admin penjualan, kasir, accounting dan ADH. Sehingga keterlibatan pemakai dalam pengembangan sistem terbatas.

Dalam hal ini bertentangan dengan teori HOT yang menjelaskan keterlibatan pemakai berhubungan dengan tingkat penggunaan, harapan dan sikap menerima atau menolak sistem, serta pendapat mengenai kelebihan dan kelemahan sistem yang digunakan untuk melakukan evaluasi pengembangan sistem informasi yang dapat mempengaruhi keberhasilan kinerja sistem informasi akuntansi pada perusahaan. Hasil pengujian hipotesis 2 pada perusahaan CV Jaya Motor menunjukkan meskipun tingkat keterlibatan dalam pengembangan sistem pada karyawan yang berhubungan dengan pengolahan data transaksi terbatas, akan tetapi kinerja sistem informasi akuntansi pada perusahaan CV Jaya Motor tetap berjalan dengan efektif dan efisien.

Hasil penelitian ini sejalan dan menudukung dengan penelitian yang dilakukan oleh Utami, dkk (2016) yang menunjukkan bahwa keterlibatan pemakai tidak berpengaruh terhadap kinerja sistem informasi akuntansi. Namun hasil penelitian ini bertentangan dengan penelitian yang dilakukan oleh Arini, dkk (2017), Abhimantra, dkk (2016) dan Antari, dkk (2015) yang menunjukkan bahwa keterlibatan pemakai berpengaruh positif dan signifikan terhadap kinerja sistem informasi akuntansi.

\section{Pengaruh Dukungan Manajemen Puncak Terhadap Kinerja Sistem Informasi Akuntansi}

Hasil pengujian hipotesis 3 pada perusahaan CV Jaya Motor menunjukkan bahwa bahwa dukungan manajemen puncak berpengaruh positif dan signifikan terhadap kinerja sistem informasi akuntansi. Hal ini menunjukkan bahwa manajemen puncak dalam perusahaan 


\section{P ISSN}

mempunyai otoritas atau wewenang terhadap karyawan untuk dapat mengatur menu sistem yang digunakan dalam perusahaan. Selain itu manajemen puncak sangat memperhatikan evaluasi kinerja sistem informasi akuntansi pada perusahaan dengan memberikan arahan dan motivasi kepada karyawan, agar karyawan melaksanakan dan bertanggung jawab terhadap tugas yang diberikan. Selain itu manajemen puncak juga memberikan apresiasi kepada karyawan yang kinerjanya baik.

Berdasarkan teori HOT dukungan manajemen puncak menekankan hubungan terhadap struktur organisasi dan lingkungan organisasi dimana adanya interaksi antara atasan dan bawahan untuk melakukan evaluasi penggunaan dan pengembangan sistem. Dalam hal ini manajemen puncak tidak hanya berperan sebagai pengambilan keputusan saja melainkan harus dapat memberikan motivasi kepada karyawan sehingga karyawan merasa percaya diri dan bertanggung jawab terhadap pekerjaannya yang berpengaruh terhadap keberhasilan kinerja sistem informasi akuntansi pada perusahaan. Hasil pengujian hipotesis 3 pada perusahaan CV Jaya Motor bahwa dengan adanya dukungan penuh dari manajemen puncak terhadap karyawan, menjadikan karyawan lebih merasa dihargai, percaya diri dan bertanggung jawab terhadap pekerjaannya sehingga kinerja sistem informasi akuntansi pada perusahaan meningkat.

Hasil penelitian ini sejalan dan mendukung dengan penelitian yang dilakukan oleh Utami, dkk (2016), Abhimantra, dkk (2016), Antari, dkk (2015) dan Fani, dkk (2015) yang menunjukkan bahwa dukungan manajemen puncak berpengaruh positif dan signifikan terhadap kinerja sistem informasi akuntansi.

\section{KESIMPULAN DAN SARAN}

\section{Kesimpulan}

Berdasarkan hasil analisis dan uji hipotesi dapat disimpulkan bahwa penggunaan teknologi informasi berpengaruh positif dan signifikan terhadap kinerja sistem informasi akuntansi, keterlibatan pemakai tidak berpengaruh terhadap kinerja sistem informasi akuntansi 


\section{P ISSN}

dan dukungan manajemen puncak berpengaruh positif dan signifikan terhadap kinerja sistem informasi akuntansi.

\section{Saran}

Bagi perusahaan CV Jaya Motor untuk dapat terus meningkatkan kinerja sistem informasi akuntansi dengan terus memperhatikan dan melakukan evaluasi

terhadap faktor-faktor yang mempengaruhi kinerja sistem informasi akuntansi, sehingga dapat terus bersaing dalam dunia bisnis yang semakin kompetitif. Bagi peneliti selanjutnya, disarankan untuk mengembangkan penelitian ini dengan menambah variabel lain atau meneliti faktor-faktor lain yang dapat mempengaruhi kinerja sistem informasi akuntansi seperti kemampuan teknik personal dan ukuran organisasi serta perlunya memperluas objek penelitian, tidak hanya satu perusahaan saja sehingga dapat diterapkan atau digeneralisasi untuk lingkup yang lebih luas.

\section{DAFTAR PUSTAKA}

Arini, Ni Kadek Ayu. 2017. "Pengaruh Penggunaan Teknologi Informasi, Keterlibatan Pemakai, Program Pelatihan dan Pendidikan Pemakai, Formalisasi Pengembangan Sistem Terhadap Kinerja Sistem Informasi Akuntansi Pada Lembaga Perkreditan Desa (LPD) Di LPD Sibetan, Bebandem, dan Macang”. E-Journal S1 Ak Universitas Pendidikan Ganesha. Vol.7, No.1.

Abhimantra, Wayan Purwa. 2016. "Analisis Faktor-Faktor Yang Memengaruhi Kinerja Sistem Informasi Akuntansi”. E-Jurnal Akuntansi Universitas Udayana. 14. 3:17821809.

Antari, Kadek Rilly Widhi. "Faktor-Faktor Yang Berpengaruh Terhadap Kinerja Sistem Informasi Akuntansi Pada Bank Perkreditan Rakyat Di Kabupaten Buleleng”. EJournal S1 Ak Universitas Pendidikan Ganesha. Vol. 3. No. 1.

Basuki, Agus Tri dan Nano Prawoto. 2016. “Analisis Regresi Dalam Penelitian Ekonomi dan Bisnis”. Jakarta: PT RajaGrafindo Persada.

Chalik, Irma Adchania. 2017. "Analisis Faktor-Faktor Yang Berpengaruh Terhadap Minat Pengguna E-Filling”. Jurnal Aplikasi Manajemen Ekonomi dan Bisnis. Vol. 2, No. 1. 


\section{P ISSN}

Fani, Luh Nanda Yogita, Nyoman Ari Surya Darmawan dan I Gusti Ayu Purnamawati. 2015. "Pengaruh Kecanggihan Teknologi Informasi, Kemampuan Teknik Pemakai, Dan Dukungan Manajemen Puncak Terhadap Kinerja Sistem Informasi Akuntansi Studi Empiris Pada PT PLN (Persero) Area Bali Utara (Kantor Pusat)”. E-Journal S1 Ak Universitas Pendidikan Ganesha. Vol. 3, No. 1.

Ghozali, Imam. 2016. “Aplikasi Analisis Multivariete Dengan Program IBM SPSS 23”. Semarang: Badan Penerbit Universitas Diponegoro.

Jogiyanto. 2009. “Sistem Teknologi Informasi”. Yogyakarta: CV Andi Offset. .2008. “Metodologi Penelitian Sistem Infomasi”. Yogyakarta: CV Andi Offset

Kasmir. 2016. “Manajemen Sumber Daya Manusia”. (Teori dan Praktik)”. Jakarta: PT. Raja Grafindo Persada.

Lubis, Arfan Ikhsan. 2010. “Akuntansi Keperilakuan”. Jakarta: Salemba Empat.

Nasution. 2001. “Metode Research”. Jakarta: PT Bumi Aksara.

Utami, Shendy Cahyaning, Dewi Saptantinah Puji Astuti dan Muhammad Rofiq Sunarko. 2016. "Pengaruh Kemampuan Pengguna Sistem Informasi, Keterlibatan Pengguna, dan Dukungan Manajemen Puncak Terhadap Kinerja Sistem Informasi Akuntansi Pada PT BTPN Area Surakarta”. Jurnal Akuntansi dan Sistem Teknologi Informasi. Vol. 12, No.2 